\title{
Complete genome sequence of a novel bat mastadenovirus $C$ strain isolated from Rhinolophus cornutus in Japan
}

\author{
Misa Katayama ${ }^{1} \cdot$ Shin Murakami ${ }^{1} \cdot$ Hiromichi Matsugo ${ }^{1,2} \cdot$ Haruhiko Kamiki $^{1} \cdot$ Marina Fuji $^{1}$. \\ Akiko Takenaka-Uema ${ }^{1} \cdot$ Taisuke Horimoto $^{1}$ (i)
}

Received: 7 October 2021 / Accepted: 23 November 2021 / Published online: 3 February 2022

(c) The Author(s), under exclusive licence to Springer-Verlag GmbH Austria, part of Springer Nature 2022

\begin{abstract}
Here, we report a novel bat adenovirus strain isolated from apparently healthy bats of the species Rhinolophus cornutus in Japan. The genome of the isolate was 36,506 bp in length and encoded at least 33 proteins. Phylogenetic analysis of the DNA polymerase amino acid sequence, which provides one demarcation criterion for adenoviral species, indicated that the isolate belongs to the species Bat mastadenovirus $C$ in the genus Mastadenovirus. Most of the encoded proteins shared high sequence similarity with those of known bat adenovirus $\mathrm{C}$ strains detected in different species of Rhinolophus, whereas the fiber protein and some E3- and E4-related proteins shared moderate similarity, and only the large E3 protein, which contains several host immune-suppression-related motifs, showed considerably lower similarity.
\end{abstract}

Bats are an important reservoir of many zoonotic viruses [1-4] including adenoviruses [5, 6]. Adenoviruses are nonenveloped icosahedral viruses with a double-stranded DNA genome that infect a wide range of vertebrate hosts from amphibians and fish to mammals. The family Adenoviridae is divided into six genera (Atadenovirus, Aviadenovirus, Ichtadenovirus, Mastadenovirus, Siadenovirus, and Testadenovirus). Mastadenoviruses infect a variety of mammalian hosts, including bats. Bat mastadenoviruses (BtAdVs) have been classified as members of the species Bat mastadenovirus A-J by the International Committee on Taxonomy of Viruses (ICTV) [7]. BtAdVs are divided into three groups depending on host family classification: group 1, comprised of members of species A, B, G, and J, isolated from Vespertilionidae bats and genetically closely related to canine

Handling Editor: T. K. Frey.

Shin Murakami

shin-murakami@g.ecc.u-tokyo.ac.jp

$\triangle$ Taisuke Horimoto

taihorimoto@g.ecc.u-tokyo.ac.jp

1 Laboratory of Veterinary Microbiology, Graduate School of Agricultural and Life Sciences, The University of Tokyo, 1-1-1 Yayoi, Bunkyo-ku, Tokyo 113-8657, Japan

2 Laboratory of Veterinary Public Health, Graduate School of Agricultural and Life Sciences, The University of Tokyo, Tokyo, Japan adenoviruses; group 2, comprised of members of species C from Rhinolophidae bats; and group 3, comprised of members of species D, E, F, H, and I from Miniopteridae and Pteropodidae bats [8].

To investigate bat viruses, we collected fecal samples from apparently healthy insectivorous Rhinolophus cornutus bats with permission from the local government in Shizuoka Prefecture of Japan in September 2020. We then inoculated antibiotic-treated fecal suspensions onto African green monkey Vero cells expressing a transmembrane protease, serine 2 (Vero/TMPRSS2), which may support the replication of certain unknown viruses [9]. A clear cytopathic effect was observed in the cells at 7 days post-inoculation. The cell supernatant was passed through a $0.22-\mu \mathrm{m}$ filter and inoculated onto fresh Vero/TMPRSS2 cells, producing an extensive cytopathic effect (Supplementary Fig. S1). This indicated that the virus had been isolated successfully. To identify the genome type of the isolate, we analyzed its growth in the presence of ribavirin or 5-iodo-2'-deoxyuridine (IUDR), which inhibit the growth of RNA and DNA viruses, respectively. Growth was inhibited with IUDR but not with ribavirin, suggesting that the isolate was a DNA virus. Then, to determine the complete genome sequence of the viral isolate, we grew it in cells for 4 days and purified it from the culture medium by ultracentrifugation with a $20 \%$ sucrose cushion. Viral DNA was extracted from the purified virus using a NucleoSpin Tissue Kit (Macherey-Nagel, Duren, Germany). A DNA library was prepared using a TruSeq 
Nano DNA Low Throughput Library Prep Kit (Illumina, San Diego, CA, USA) and subjected to next-generation sequencing (NovaSeq 6000, Illumina). The sequence dataset was assembled de novo using CLC Genomics Workbench software (v.8, CLC bio, Aarhus, Denmark), and sequence comparisons indicated that the isolate was a BtAdV strain, which was named Rc-kw20. The complete genome of Rc-kw20 is 36,506 nucleotides long with $54 \% \mathrm{G}+\mathrm{C}$ content. The complete nucleotide sequence has been deposited in the DDBJ/ GenBank database under the accession number MZ683934.

The full genomic nucleotide sequence was analyzed phylogenetically (Fig. 1a). The phylogenetic tree (a)

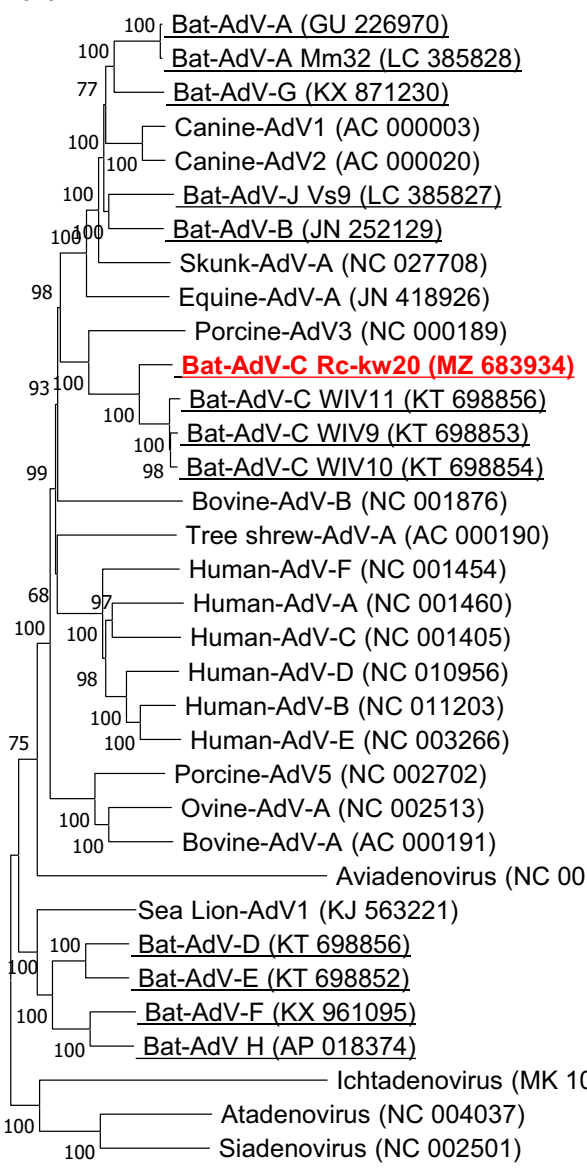

0.2 (b)

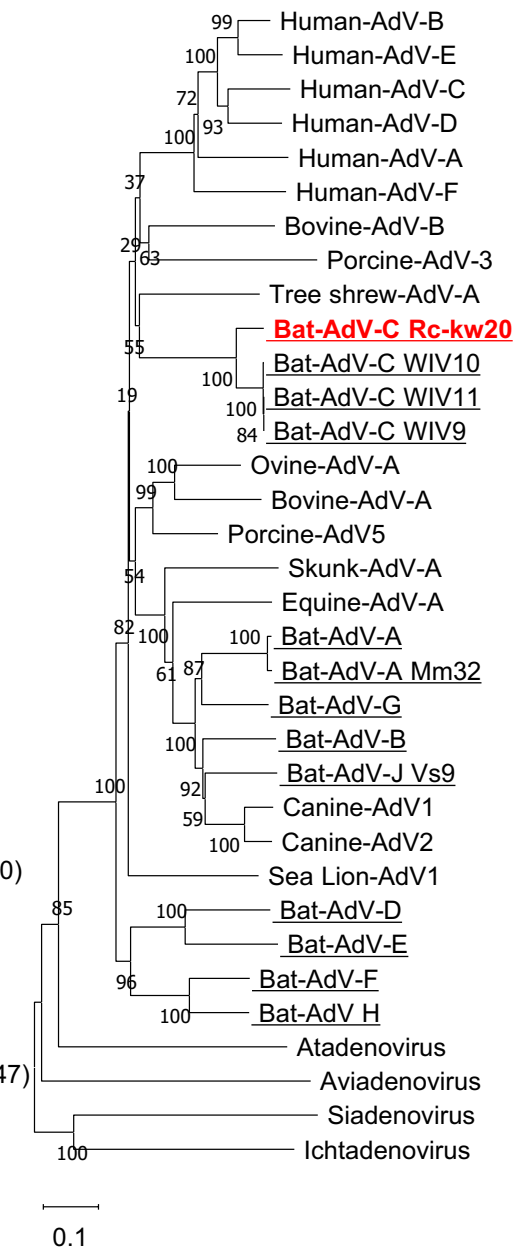

(c)

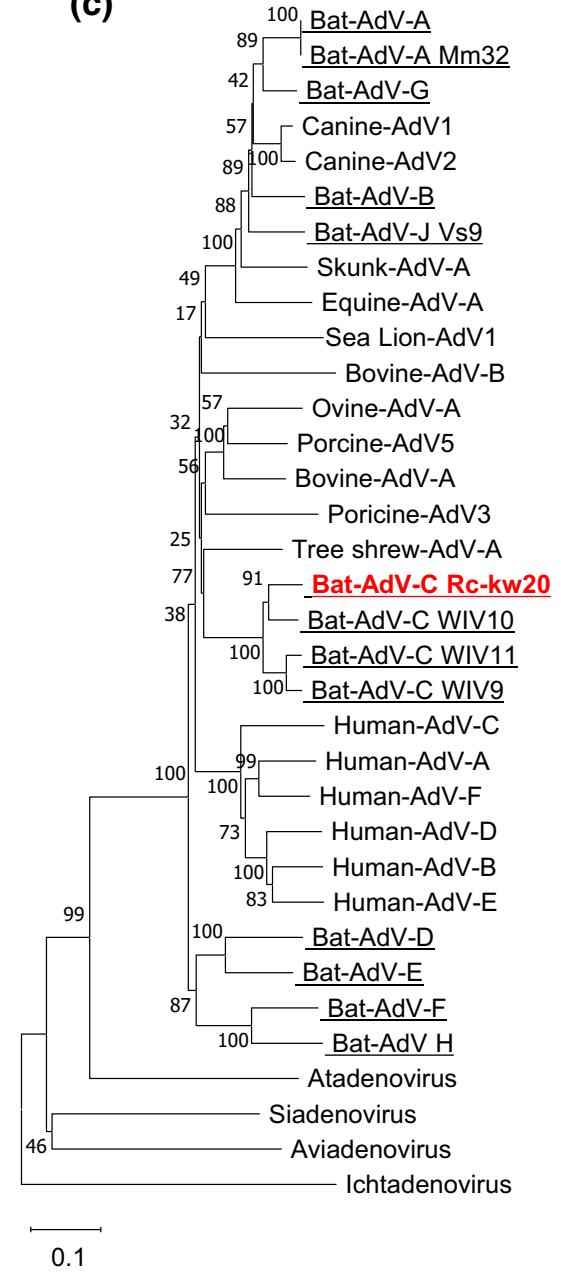

(d)

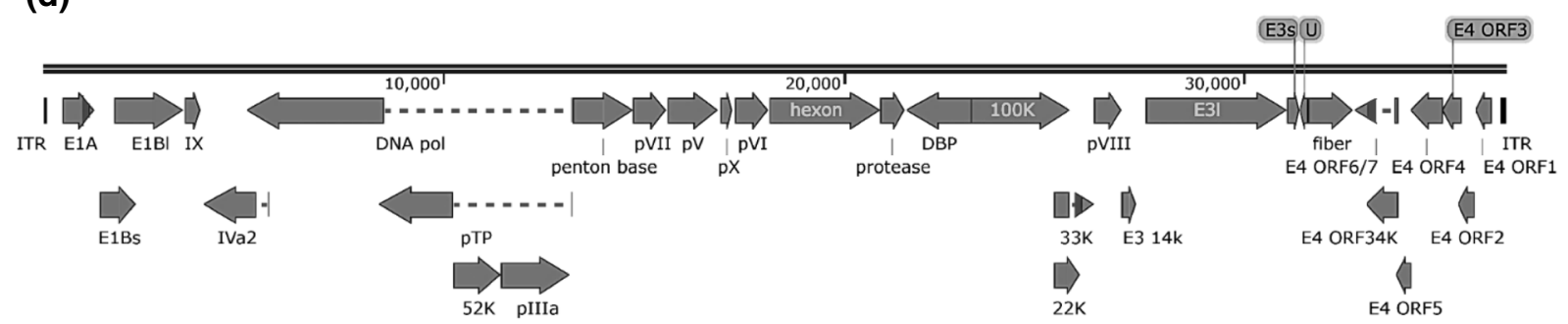

Fig. 1 Genetic analysis of bat mastadenoviruses. Phylogenetic trees based on (a) full-length nucleotide sequences, (b) DNA polymerase amino acid sequences, and (c) hexon amino acid sequences were constructed by the neighbor-joining method with 1,000 bootstrap replicates using MEGA X software. Bootstrap values are indicated as percentages at the nodes. Bars indicate evolutionary distance in units of substitutions per site. All bat mastadenoviruses are underlined, and the novel isolate identified in this study is shown in bold red. (d) Gene map of BatAdV-Rc-kw20 in which genes are shown as grey arrows and ITR sequences are shown as black rectangles 
Table 1 Amino acid sequence identity of Rc-kw20 proteins to those of other BtAdV-C strains

\begin{tabular}{|c|c|c|c|c|}
\hline \multirow[t]{2}{*}{ Gene product } & \multirow{2}{*}{$\begin{array}{l}\text { Genomic position (orienta- } \\
\text { tion*) }\end{array}$} & \multicolumn{3}{|c|}{ Identity (\%) } \\
\hline & & WIV9 & WIV10 & WIV11 \\
\hline E1A & $529-1024,1115-1310(\mathrm{R})$ & 72.3 & 72.3 & 72.8 \\
\hline E1Bs & $1457-2368(\mathrm{R})$ & 69.4 & 68.2 & 68.2 \\
\hline E1B1 & $1822-3528(\mathrm{R})$ & 68.0 & 68.1 & 68.3 \\
\hline pIX & $3578-3964(\mathrm{R})$ & 80.3 & 80.3 & 80.3 \\
\hline IVa2 & $4032-5362,5641-5653(\mathrm{~L})$ & 94.2 & 94.0 & 94.2 \\
\hline pol & $\begin{array}{l}5123-8575,13227-13235 \\
\quad(\mathrm{~L})\end{array}$ & 89.8 & 89.8 & 89.8 \\
\hline pTP & $\begin{array}{l}\text { 8422-10284, 13227-13235 } \\
\text { (L) }\end{array}$ & 90.6 & 90.4 & 90.4 \\
\hline $52 \mathrm{k}$ & $10277-11455(\mathrm{R})$ & 92.8 & 92.8 & 92.8 \\
\hline pIIIa & $11484-13184(\mathrm{R})$ & 90.9 & 90.7 & 90.9 \\
\hline Penton base & $13265-14767(\mathrm{R})$ & 89.0 & 89.0 & 89.2 \\
\hline pVII & $14773-15588(\mathrm{R})$ & 91.2 & 91.2 & 91.2 \\
\hline $\mathrm{pV}$ & $15648-16880(\mathrm{R})$ & 85.2 & 85.4 & 85.2 \\
\hline $\mathrm{pX}$ & $16957-17238(\mathrm{R})$ & 95.7 & 95.7 & 95.7 \\
\hline pVI & $17236-18129(\mathrm{R})$ & 82.4 & 82.4 & 82.5 \\
\hline Hexon & $18178-20928(\mathrm{R})$ & 88.8 & 90.9 & 89.2 \\
\hline Protease & $20943-21563(\mathrm{R})$ & 90.5 & 91.5 & 91.0 \\
\hline DBP & 21592-23205 (L) & 78.8 & 78.7 & 78.7 \\
\hline $100 \mathrm{k}$ & $23219-25687(\mathrm{R})$ & 85.2 & 85.1 & 85.3 \\
\hline $33 \mathrm{k}$ & $\begin{array}{l}25302-25699,25935- \\
26289(\mathrm{R})\end{array}$ & 79.8 & 79.5 & 80.1 \\
\hline $22 \mathrm{k}$ & $25302-25922(\mathrm{R})$ & 75.9 & 75.5 & 76.2 \\
\hline pVIII & $26292-26984(\mathrm{R})$ & 96.1 & 96.1 & 96.5 \\
\hline E3 $14 k$ & $26971-27351(\mathrm{R})$ & 69.4 & 68.5 & 68.5 \\
\hline E31 & 27579-31118 (R) & 34.6 & 33.6 & 31.8 \\
\hline E3s & $31120-31419(\mathrm{R})$ & 57.6 & 57.6 & 57.6 \\
\hline U exon & $31434-31610(\mathrm{~L})$ & 52.6 & 52.6 & 52.6 \\
\hline Fiber & $31632-32753(\mathrm{R})$ & 60.1 & 50.3 & 48.0 \\
\hline E4 34k & $33085-33882(\mathrm{~L})$ & 75.7 & 74.5 & 75.3 \\
\hline E4 ORF6/7 & $\begin{array}{l}32782-33059,33791- \\
33882(\mathrm{~L})\end{array}$ & 62.4 & 62.4 & 62.4 \\
\hline E4 ORF5 & 33827-34192(L) & 83.6 & 79.8 & 80.7 \\
\hline E4 ORF4 & $34194-34970(\mathrm{~L})$ & 51.6 & 50.4 & 51.6 \\
\hline E4 ORF3 & 34997-35464 (L) & 56.2 & 56.2 & 55.4 \\
\hline E4 ORF2 & $35391-35768(\mathrm{~L})$ & 67.2 & 67.2 & 66.4 \\
\hline E4 ORF1 & 35799-36212 (L) & 50.7 & 50.7 & 53.7 \\
\hline
\end{tabular}

*Strand orientation; L, leftward; R, rightward

indicated that strain Rc-kw20 was positioned in the same cluster with previous BtAdV-C strains, all of which had been detected in Rhinolophus sinicus bats in China, suggesting that Rc-Kw20 belongs to the species Bat mastadenovirus $C$ in the genus Mastadenovirus. The full genomic nucleotide sequence of Rc-kw20 was $83.8 \%$, $83.9 \%$, and $83.7 \%$ identical to BtAdV-C strains, WIV9, WIV10, and WIV11, respectively (GenBank accession numbers KT698853-5).
Open reading frames (ORFs) were predicted using SnapGene Viewer software (SnapGene v.5; GSL Biotech, San Diego, CA, USA) (Table 1), and 33 putative ORFs were identified. Comparisons of the DNA polymerase amino acid sequences of Rc-kw20 and other BtAdV-C strains, which provide one demarcation criterion for adenoviral species [10], showed that they were nearly $90 \%$ identical (Table 1). Phylogenetic analysis confirmed that the Rc-kw20 strain was positioned in the BtAdV-C cluster (Fig. 1b), and this was supported by analysis using hexon protein amino acid sequences (Fig. 1c), confirming that $\mathrm{Rc}-\mathrm{Kw} 20$ is a BtAdV-C strain and that Rhinolophus cornutus should be included as a susceptible host for group 2 BtAdV.

We also generated a genomic map, which included the 54-bp-long inverted terminal repeat (ITR) sequences (Fig. 1d). Twenty of the 33 proteins encoded by Rc-kw20 shared high sequence similarity (more than $80 \%$ identity) with those of previously characterized BtAdV-C strains, whereas the fiber protein and several E3- and E4-related proteins shared moderate similarity (ranging from $48.0 \%$ to $67.2 \%$ sequence identity), and only the large E3 (E31) protein, which contains host immune-suppression-related motifs [11], showed considerably lower similarity $(31.8 \%$ to $34.6 \%$ sequence identity) (Table 1). Possible functional differences involving proteins with lower sequence similarity might determine the host specificity of BtAdV-C strains.

Recent studies have indicated that Rhinolophus spp. bats may represent an ancestral host for severe acute respiratory syndrome coronavirus 2 (SARS-CoV-2), which causes COVID-19. Indeed, related bat sarbecoviruses have been detected in Rhinolophus affinis, $R$. sinicus, $R$. pusillus, $R$. malayanus, $R$. acuminatus, and $R$. shameli in Asian countries [12-17]. In addition, we detected a bat sarbecovirus in $R$. cornutus in Japan [18]. Further studies are needed to assess the zoonotic potential of bat viruses inhabiting these Rhinolophus species, including BtAdV-C.

Supplementary Information The online version contains supplementary material available at https://doi.org/10.1007/s00705-021-05357-8.

Funding This work was supported by the Japan Agency for Medical Research and Development (AMED) under Grant numbers JP21fk0108602 and JP21fk0108615.

\section{Declarations}

Conflict of interest The authors declare no conflict of interest.

Ethical approval This study did not involve experiments with human participants performed by any of the authors. Experiments with bat samples were approved by the Animal Experiment Committee of the Graduate School of Agricultural and Life Sciences at the University of Tokyo (approval number P21-058). 


\section{References}

1. Lau SK, Woo PC, Li KS, Huang Y, Tsoi HW, Wong BH, Wong SS, Leung SY, Chan KH, Yuen KY (2005) Severe acute respiratory syndrome coronavirus-like virus in Chinese horseshoe bats. Proc Natl Acad Sci USA 102:14040-14045. https://doi.org/10. 1073/pnas.0506735102

2. Epstein JH, Anthony SJ, Islam A, Kilpatrick AM, Ali Khan S, Balkey MD, Ross N, Smith I, Zambrana-Torrelio C, Tao Y, Islam A, Quan PL, Olival KJ, Khan MSU, Gurley ES, Hossein MJ, Field HE, Fielder MD, Briese T, Rahman M, Broder CC, Crameri G, Wang LF, Luby SP, Lipkin WI, Daszak P (2020) Nipah virus dynamics in bats and implications for spillover to humans. Proc Natl Acad Sci USA 117:29190-29201. https://doi.org/10.1073/ pnas. 2000429117

3. Johnson N, Vos A, Freuling C, Tordo N, Fooks AR, Müller T (2010) Human rabies due to lyssavirus infection of bat origin. Vet Microbiol 142:151-159. https://doi.org/10.1016/j.vetmic.2010.02. 001

4. Kuzmin IV, Niezgoda M, Franka R, Agwanda B, Markotter W, Breiman RF, Shieh WJ, Zaki SR, Rupprecht CE (2010) Marburg virus in fruit bat, Kenya. Emerg Infect Dis 16:352-354. https:// doi.org/10.3201/eid1602.091269

5. Kobayashi T, Matsugo H, Maruyama J, Kamiki H, Takada A, Maeda K, Takenaka-Uema A, Tohya Y, Murakami S, Horimoto $\mathrm{T}$ (2019) Characterization of a novel species of adenovirus from Japanese microbat and role of CXADR as its entry factor. Sci Rep 9:573. https://doi.org/10.1038/s41598-018-37224-z

6. Borkenhagen LK, Fieldhouse JK, Seto D, Gray GC (2019) Are adenoviruses zoonotic? A systematic review of the evidence. Emerg Microbes Infect 8:1679-1687. https://doi.org/10.1080/ 22221751.2019.1690953

7. Walker PJ, Siddell SG, Lefkowitz EJ, Mushegian AR, Adriaenssens EM, Dempsey DM, Dutilh BE, Harrach B, Harrison RL, Hendrickson RC, Junglen S, Knowles NJ, Kropinski AM, Krupovic M, Kuhn JH, Nibert M, Orton RJ, Rubino L, Sabanadzovic S, Simmonds P, Smith DB, Varsani A, Zerbini FM, Davison AJ (2020) Changes to virus taxonomy and the statutes ratified by the International Committee on Taxonomy of Viruses (2020). Arch Virol 165:2737-2748. https://doi.org/10.1007/ s00705-020-04752-x

8. Ogawa H, Kajihara M, Nao N, Shigeno A, Fujikura D, Hang'ombe BM, Mweene AS, Mutemwa A, Squarre D, Yamada M, Higashi H, Sawa H, Takada A (2017) Characterization of a novel bat adenovirus isolated from straw-colored fruit bat (Eidolon helvum). Viruses 9:371. https://doi.org/10.3390/v9120371

9. Shirogane $Y$, Takeda M, Iwasaki M, Ishiguro N, Takeuchi H, Nakatsu Y, Tahara M, Kikuta H, Yanagi Y (2008) Efficient multiplication of human metapneumovirus in Vero cells expressing the transmembrane serine protease TMPRSS2. J Virol 82:8942-8946. https://doi.org/10.1128/JVI.00676-08

10. Benko M, Harrach B, Both GW, Russell WC, Adair BM, Adam E, deJong JC, Hess M, Johnson M, Kajon A, Kidd AH, Lehmkuhl
HD, Li Q, Mautner V, Pring-Akerblom P, Wadell G (2005) Adenoviridae. In: Fauquet CM, Mayo MA, Maniloff J, Desselberger U, Ball LA (eds) Virus taxonomy. Eighth report of the international committee on the taxonomy of viruses. Elsevier Academic Press, San Diego, pp 213-228

11. Tan B, Yang XL, Ge XY, Peng C, Zhang YZ, Zhang LB, Shi ZL (2016) Novel bat adenoviruses with an extremely large E3 gene. J Gen Virol 97:1625-1635. https://doi.org/10.1099/jgv.0.000470

12. Li LL, Wang JL, Ma XU, Sun XM, Li JS, Yang XF, Shi WF, Duan ZJ (2021) A novel SARS-CoV-2 related coronavirus with complex recombination isolated from bats in Yunnan province, China. Emerg Microbes Infect 10:1683-1690. https://doi.org/10. 1080/22221751.2021.1964925

13. Hassanin A, Tu VT, Curaudeau M, Csorba G (2021) Inferring the ecological niche of bat viruses closely related to SARS-CoV-2 using phylogeographic analyses of Rhinolophus species. Sci Rep 11:14276. https://doi.org/10.1038/s41598-021-93738-z

14. Wacharapluesadee S, Tan CW, Maneeorn P, Duengkae P, Zhu F, Joyjinda Y, Kaewpom T, Chia WN, Ampoot W, Lim BL, Worachotsueptrakun K, Chen VC, Sirichan N, Ruchisrisarod C, Rodpan A, Noradechanon K, Phaichana T, Jantarat N, Thongnumchaima B, Tu C, Crameri G, Stokes MM, Hemachudha T, Wang LF (2021) Evidence for SARS-CoV-2 related coronaviruses circulating in bats and pangolins in Southeast Asia. Nat Commun 12:972. https://doi.org/10.1038/s41467-021-21240-1

15. Zhou P, Yang XL, Wang XG, Hu B, Zhang L, Zhang W, Si HR, Zhu Y, Li B, Huang CL, Chen HD, Chen J, Luo Y, Guo H, Jiang RD, Liu MQ, Chen Y, Shen XR, Wang X, Zheng XS, Zhao K, Chen QJ, Deng F, Liu LL, Yan B, Zhan FX, Wang YY, Xiao GF, Shi ZL (2020) A pneumonia outbreak associated with a new coronavirus of probable bat origin. Nature 579:270-273. https:// doi.org/10.1038/s41586-020-2012-7

16. Zhou H, Chen X, Hu T, Li J, Song H, Liu Y, Wang P, Liu D, Yang J, Holmes EC, Hughes AC, Bi Y, Shi W (2020) A novel bat coronavirus closely related to SARS-CoV-2 contains natural insertions at the S1/S2 cleavage site of the spike protein. Curr Biol 30:2196-2203.e3. https://doi.org/10.1016/j.cub.2020.05.023

17. Lau SKP, Luk HKH, Wong ACP, Li KSM, Zhu L, He Z, Fung J, Chan TTY, Fung KSC, Woo PCY (2020) Possible bat origin of severe acute respiratory syndrome coronavirus 2. Emerg Infect Dis 26:1542-1547. https://doi.org/10.3201/eid2607.200092

18. Murakami S, Kitamura T, Suzuki J, Sato R, Aoi T, Fujii M, Matsugo H, Kamiki H, Ishida H, Takenaka-Uema A, Shimojima M, Horimoto T (2020) Detection and characterization of bat sarbecovirus phylogenetically related to SARS-CoV-2, Japan. Emerg Infect Dis 26:3025-3029. https://doi.org/10.3201/eid2612.203386

Publisher's Note Springer Nature remains neutral with regard to jurisdictional claims in published maps and institutional affiliations. 